\title{
Perspektywy ujęcia odpowiedzialności
}

\section{Interpretation Perspectives of Responsibility}

\author{
Bożena Niećko-Bukowska \\ Instytut Językoznawstwa, Uniwersytet im. Adama Mickiewicza \\ al. Niepodległości 4, 61-874 Poznań \\ bnieckodamu.edu.pl
}

\begin{abstract}
The purpose of this article is to analyze the possible perspectives relating to responsibility. The purpose of the initial section is to describe the development of the notion of responsibility. The most important issues are the problem of biosferic responsibility and the phenomenons of responsibility including the call to account, arraign or to bear the responsibility.
\end{abstract}

\section{Wstęp}

Niniejszy tekst będzie próbą przedstawienia możliwych postaci odpowiedzialności. We wstępie znajduje się krótki rys rozwoju tego pojęcia. W dalszej części podjęta została analiza, niektórych perspektyw mówienia o odpowiedzialności. Istotna część uwagi poświęcona jest zagadnieniu odpowiedzialności biosferycznej oraz sytuacjom zachodzenia fenomenów zjawiska odpowiedzialności w kontekście sądowego modelu odpowiedzialności.

\section{Rozwój pojęcia odpowiedzialności.}

Problem odpowiedzialności przynależy do filozofii człowieka i trudno owocnie go rozważać z dala od niej. Śledząc dzieje myślenia filozoficznego, autor Filozofii odpowiedzialności XX wieku, zauważa, że w czasach paradygmatu starożytnego dominował rozum, obiektywność a podstawowym pojęciem była prawda. Czasy nowożytne przyniosły ze sobą wolę, subiektywność oraz takie kluczowe pojęcie jak wolność. Trzecim paradygmatem filozofii jest paradygmat dialogiczny, związany $\mathrm{z}$ pojęciem odpowiedzialności ${ }^{1}$.

„Odpowiedzialność” wywodząca się od łacińskiego słowa respondere, oznaczającego „odpowiadać”, przemyca w swoim znaczeniu językową interakcje. O pociaganiu do 
odpowiedzialności zarówno ludzi, jak i zwierząt w czasach starożytnych pisał Platon ${ }^{2} . \mathrm{Z}$ „koncepcja jednostki ludzkiej” i „odpowiedzialności indywidualnej” wystąpił Demokryt z Abdery, dla którego ani obawa przed karą, ani nakaz prawny nie były silniejsze od motywacji wewnętrznej i przekonania o słuszności i prawości czynu³. Sokrates, filozof słynący $\mathrm{z}$ odkrycia istoty człowieka, zdefiniował człowieka jako myślącą i działającą świadomość. Z czasem odpowiedzialność zaczęto przypisywać wyłącznie ludziom, chociaż jeszcze $\mathrm{w}$ czasach Oświecenia można natrafić na przypadki pociagania do odpowiedzialności zwierząt ${ }^{4}$. Niewątpliwie taki sądowy model znalazł swoje odbicie w ramach religii chrześcijańskiej, w odpowiedzialności przed Bogiem w dniu Sądu Ostatecznego. Bóg nie tylko objawia ludziom zbiór ocen i norm moralnych, ale stoi na straży ich przestrzegania, a po śmierci człowieka pełni rolę sędziego wyrokującego zgodnie $\mathrm{z}$ objawionym kodeksem. Idea odpowiedzialności za wybór maksymy postępowania pojawiła się w XVIII wieku w filozofii niemieckiej. Dzięki I. Kantowi człowiek zyskuje nową perspektywę oglądu odpowiedzialności - samoodpowiedzialność. F.W.J. Schelling proponował koncepcje odpowiedzialności elitarnej, J. G. Fichte występował z pomysłem odpowiedzialności zbiorowej, a Hegel role trybunału powierzał historii. Pierwsze wyraźne próby opisywania egzystencji ludzkiej z perspektywy kategorii odpowiedzialniści pojawiły się S. Kierkegaarda i F. Nietzschego. Ogłaszana przez tego ostatniego „śmierć Boga" niosła za sobą nie zwolnienie od odpowiedzialności, ale jej spotęgowanie. Dla Nietzschego zgoda na odpowiadanie przed instancją jest rezultatem braku umiejętności odpowiadania tylko przed sobą a tylko odpowiedzialność przed sobą jest rzeczywistą odpowiedzialnością Jednakże, to dopiero za sprawą egzystencjalizmu horyzonty odpowiedzialności uległy takiemu poszerzeniu, że człowiek stał się odpowiedzialnym za swoje czyny, niezależnie od tego, czy zostanie za nie pociągnięty do odpowiedzialności. J. P. Sartre w dziele „Byt i nicość”, zabsolutyzował odpowiedzialność. Człowiek będąc skazanym na wolność zostaje zarazem skazany na odpowiedzialność. Odpowiedzialność staje się absolutną odpowiedzialnością wewnętrzną, totalną odpowiedzialnością za siebie. G. Picht zauważa, że warunki możliwej odpowiedzialności tkwią w sytuacji dziejowej, i chcąc zdefiniować odpowiedzialność należy wyjść od zadań a nie od podmiotu. Człowiek odpowiedzialny jest za dzianie się, za wszystko to, co, się wydarza. Tak pojęcie odpowiedzialności dotyka zagadnienia losu przyszłych pokoleń, gdyż odpowiedzialność za dzieje jest odpowiedzialnością za zachowanie ludzkości ${ }^{5}$.

W języku polskim pojęcie odpowiedzialności do XIX-go wieku używane było jako wyrażenie typu: „ktoś odpowiada za coś (o coś)”6. Tak rozumiana odpowiedzialność związana jest $\mathrm{z}$ odpowiadaniem na wezwanie, $\mathrm{z}$ udzielaniem odpowiedzi, dawaniem odprawy, zawiadamianiem. „Odpowiadać” oznacza: replikować, odrzec, odeprzeć, odcinać się, odpalić, odmruknąć, odszczekać... Z perspektywy „odpowiadania na coś” odpowiedzialność nabiera charaktru mowy. Ale „odpowiadać” występuje także w innych kontekstach, np.: „odpowiadać za wychowanie dziecka, za wykonanie pracy”. Rozumienie powyższe stosowane bywa jako ponoszenie odpowiedzialności za czyjeś bezpieczeństwo. Słyszy się, że odpowiedzialność spoczywa na czyichś barkach, ciąży na kimś, spada na

\footnotetext{
2 [Platon 1960: Prawa 837 E - 874 A]

3 [Wesoły 1994: 51-54]

4 [Filek 1996: 23; Ossowska 1983: 399-403]

${ }^{5}$ [Filek 1996: 16-19; 2003: 205-210]

${ }^{6}$ [Dokurno 1993: 85]
} 
kogoś. „Odpowiadać” bywa też łączone $\mathrm{z}$,pokutować”, kiedy to za brak odpowiedzialności należy zapłacić/odpowiedzieć głową, życiem ${ }^{7}$.

Na pytanie, - kto może być odpowiedzialny w historii języka myśli polskiej padały odpowiedzi wskazujące różnorodność spojrzeń. Czynnikiem ograniczającym odpowiedzialność był np. wiek. Pytano czy dzieci mogą odpowiadać, zastanawiano się nad ich odpowiedzialnością: „O co dzieci winny na pozew odpowiadać [...]”. Ponadto zakres odpowiedzialności mógł podlegać zmianie z uwagi na status społeczny: „Persony Duchowne, jako Księża, Mnisi, jeśli przed Prawem Świeckim na kogo żałują, tamże też obwinionemu powinni odpowiadać, o co by na nie żałował"8. Odpowiadać można było przed Carem: „On komendant, on za to przed Carem odpowie [...]”,; przed Synem Boga: „Kto $\mathrm{z}$ nas dał sobie lub da wydrzeć $\mathrm{z}$ ducha uczucie, $\mathrm{w}$ jakimeśmy zeszli się $\mathrm{w}$ dzień Obrzezania Pańskiego, ten za to odpowie przed Chrystusem Panem"10. Powoływano też nowe organy, przed którymi jednostki miały odpowiadać np.: Trybunał Rewolucyjny „,miał mieć prawo pociagania członków rządu do odpowiedzialności za niespełnienie gorliwe swoich obowiązków" "11. W zależności od tego, gdzie sytuowano trybunał oraz instancję odpowiedzialności postulowano odpowiedzialność w wymiarze: metafizycznym, społecznym czy samoodpowiedzialność.

\section{Rodzaje odpowiedzialności}

Odpowiedzialność może przybrać postać odpowiedzialności prawnej, moralnej, politycznej, rodzicielskiej, nauczycielskiej... Odpowiedzialność prawna: rodzica, nauczyciela, lekarza jest zawsze odpowiedzialnością przed prawem. Odpowiedzialność moralna: rodzica, nauczyciela, polityka związana jest $\mathrm{z}$ takim wymiarem, który za podstawę przyjmuje ogół głoszonych ocen i norm w danym czasie przez dane społeczeństwo. Czasem odpowiedzialność prawna funkcjonuje wraz $\mathrm{z}$ moralną. Niejednokrotnie drogowskazem dla odpowiedzialnych działań jednostki nie jest norma o charakterze prawnym, ale poczucie powinności, wyrzut sumienia, zmysł moralny.

Mówienie o odpowiedzialności prawnej czy moralnej wymaga na wstępie podania warunków niezbędnych dla zachodzenia zjawiska przypisania odpowiedzialności. M. Ossowska analizując zagadnienie własności, jakie przedmiot musi posiadać, by podlegał ocenie moralnej, formułuje następujące warunki odpowiedzialności: świadomość istoty podejmowanego czynu oraz możność dysponowania swoim działaniem. Jeśli czyn ludzki ma świadomy charakter, to może podlegać pochwale lub nagannie. Przy podleganiu ocenie moralnej zwraca się uwagę na to, czy sprawca posiadał prawdziwe przekonania, co do materii własnego czynu, czy zdawał sobie sprawę z konsekwencji własnych poczynań, czy działał $\mathrm{z}$ przekonaniem, że to, co robi, jest dobre/złe i dlatego, że jest to takie. Podstawowym warunkiem podlegania ocenie moralnej jest po pierwsze zasób wiedzy o czynie dokonywanym i jego skutkach, oraz po drugie pewne nastawienie woli. Ten zespół wiadomości i chcenia składa się na umyślność ${ }^{12}$.

Do działania rozumnego, działający jest w stanie wyznaczyć samego siebie. Za zachowanie świadome uchodzi takie, które cechuje odpowiedzialną - świadomą i myślącą istotę. Ponadto człowiek staje się przedmiotem oceny moralnej, gdy w swoim

\footnotetext{
${ }^{7}$ [Skorupka 1988: 119, 149].

8 [Groicki 1559: t 4, za: Mayenowa 1966-1991: t. I-XX (A-OD)].

9 [Mickiewicz 1979: X 151]

${ }^{10}$ [Mickiewicz (1846 - 1855): L 3, 78, za: Mayenowa, 1962].

11 [Daniłowski 1908: 311 za: Doroszewski: 1958]

12 [1994: 212 - 221]
} 
postępowaniu jest wolny. Możność ludzka może posiadać charakter możności wewnętrznej jak i zewnętrznej. T. Kotarbiński pisał, że ,zewnętrzna możność zachodzi, gdy nic poza obrębem samego sprawcy nie udaremnia urzeczywistnienia jego zamiaru, wewnętrzna, gdy on sam posiada niezbędne dyspozycje, czyli zdolności, które, jak się zdaje, można sprowadzić do czterech rubryk, mianowicie: siły, woli, wiedzy i sprawności"13.

Dla M. Schelera każdy człowiek jest odpowiedzialny. Chociaż o osobie można orzec, że jest niepoczytalna, to nie oznacza zarazem, że nie jest odpowiedzialna. Filozof ten przyjmuje, ze nie ma stanu zniesienia odpowiedzialności, lecz są tylko chwilowe stany niepoczytalności. Osoba pomimo okresowego uznania za niepoczytalna, pozostaje odpowiedzialna. Zgodne $\mathrm{z}$ tym, poczytalny ${ }^{14}$ człowiek jest odpowiedzialny, bo przypisywalność- czy poczytalność - zakłada odpowiedzialność, jednakże ten, kto jest odpowiedzialny może być niepoczytalny, gdyż odpowiedzialność nie pociąga przypisywalności ${ }^{15}$. Osoba poczytalna ponosi konsekwencje czynu, zaś niepoczytalna jest od nich zwolniona. Ten drugi przypadek nie postuluje odpowiedzialności karnej.

Odpowiedzialność retrospektywna dotycząca przeszłych działań i zaniechań, jest związana z mówieniem o ponoszeniu konsekwencji za skutki działań, za nieodwracalne następstwa zdarzeń. Takie ujęcie odpowiedzialności, chociaż często za podstawę ma poczucie krzywdy i domaga się moralnej sprawiedliwości, funkcjonuje w wymiarze prawa, sankcji prawnych. Zarówno jej indywidualny, jak i zbiorowy charakter kształtują problematykę odpowiedzialności za to, co minione. Odpowiedzialność jednostki za czyny dokonane, w sferze moralnej często dotyka zagadnienia wyrzutów sumienia. Żal, wstyd, zaniedbanie, poczucie winy to psychiczne ślady dla dociekań nad fenomenem odpowiedzialności retrospektywnej.

Z koncepcją odpowiedzialności zbiorowej, wspólnoty, narodu, rodzaju ludzkiego za proces dziejowy, można spotkać się u J.G. Fichte. Filozof ten w Teorii Wiedzy podaje, że podmiot transcendentalny stanowi ,pierwotną zasadę naczelną" systemu filozofii. Absolutny „podmiot” to „Ja, które samo siebie ustanawia” 16 . Mechanizm odpowiedzialności zbiorowej czynił odpowiedzialnymi tych, którzy faktycznie nie byli sprawcami czynu. Asymetria między zjawiskiem bycia odpowiedzialnym a pociaganiem do odpowiedzialności, poczuciem odpowiedzialności a jej ponoszeniem to elementy tego mechanizmu. Retrospektywna odpowiedzialność zbiorowa za winnych poczytuje nierzadko dopiero potomków pokolenia, które było faktycznym sprawcą czynu. L. Kołakowski zastanawiając się ideą odpowiedzialności zbiorowej, odpowiedzialności za to, czego nie uczyniliśmy, a co jednak nas obciąża dochodzi do wniosku, że chociaż nie jesteśmy zobowiązani prawem do odpowiadania za grzechy przodków, to jednak ,jest to sprawa zdrowia duchowego narodu, byśmy poczuwali się do odpowiedzialności i gdy trzeba, do winy i wstydu"17.

O ile dla zjawiska odpowiedzialności retrospektywnej charakterystyczny może być „wyrzut sumienia”, o tyle dla odpowiedzialności perspektywicznej będzie nim „poczucie

\footnotetext{
${ }^{13}$ [1934: 17-18; Ossowska 1994: 221]

${ }^{14}$ Zdaniem Znamierowskiego za poczytalnego uchodzi ten, kto „rozumie, co jest dobre, a co złe moralnie, względnie ten, kto rozumie, co jest nakazane i zakazane przez normy obowiązujące; dalej, kto zdolny jest powziąc zły zamiar i planowo go w czyn wprowadzić; kto wreszcie zdolny jest panować nad swymi impulsami ruchowymi, kładąc na nie powściąg wedle swojej woli". [1957: 108]

${ }^{15}$ [Filek 2003: 42-45].

${ }^{16}$ [1996: 83, 90].

${ }^{17}$ [1997: 54, 56]
} 
powinności”, „zmysł moralny”. D. Birnbacher zaproponował trzy komponenty, na których można oprzeć odpowiedzialność za przyszłość. Sa to: świadomość przyszłości, ocena przyszłości i zorientowanie na przyszłość w działaniu ${ }^{18}$. Działanie mową w ramach tak pojętej odpowiedzialność ma kluczowe znaczenie dla wytyczania kierunku działań człowieka wobec świata przyrody. Z pozycji teraźniejszości, z troski o przyszłe dobro, które można zrealizować, lub zło, które można powstrzymać, rodzi się odpowiedzialność za przyszłość.

Nierzadkie jest przeświadczenie, że wychowanie moralne jednostek obok tego, że musi uwzględniać zasady psychologiczne, reakcje umysłowe i uczuciowe dzieci czy młodzieży, to „W ostatecznym rozrachunku treść i inspiracja pochodzić będą $\mathrm{z}$ moralnych, filozoficznych i religijnych przekonań wychowawców: nauczycieli i rodziców"19. Takie założenia tym mocniej podkreślają wagę i konieczność mówienia o moralnej odpowiedzialności rodzicielskiej, nauczycielskiej, czy politycznej. Odpowiedzialność rodzicielską ustanowioną przez naturę, cechuje bezpośredniość i bliskość z przedmiotem odpowiedzialności oraz niezależność od uprzedniego uznania czy wyboru, gdyż „immanentna powinność bycia” przedmiotu odpowiedzialności domaga się a priori i całkowicie jednostronnie swego wykonawcy" 20 . Niestety nieodpowiedzialnie postępującego ojca dziecko nie może wymienić na innego, odpowiedzialniejszego. Dla $\mathrm{H}$. Jonasa odpowiedzialność rodzicielska stanowi archetyp wszelkiej odpowiedzialności. Podmiot odpowiedzialności - rodzic, odpowiedzialny jest za dziecko - przedmiot odpowiedzialności (w całokształcie wraz ze wszystkimi jego możliwościami, a nie jedynie potrzebami) przed trybunałem i zarazem instancją, jaką będzie/jest ów przedmiot odpowiedzialności w przyszłości. Cechą charakterystyczną tego przykładu odpowiedzialności jest fakty kruchości tego bytu, jaki jest przedmiotem odpowiedzialności. Silnie uwypukla to element troski moralnej i obowiązku wobec dziecka, które zdane jest na rodzica.

Trzy powszechne metody wychowawcze stosowane przez rodziców to: podkreślanie władzy, pozbawiania miłości, oraz wyjaśnianie ${ }^{21}$. Odpowiedzialna jednostka stwarza odpowiedzialną rzeczywistość. W wymarzonym przez Platona państwie nie bez znaczenia było wyszukanie młodych ludzi obdarzonych autentyczną naturą filozoficzną i ich wychowanie. $\mathrm{Na}$ rodzicach, współsprawcach istnienia dziecka, ciąży obowiązek zapewnienia mu dobrych warunków do rozwoju, ale przecież nie tylko fizycznego. Tym lepiej, kiedy troska o dziecko ma swoje źródło w poczuciu odpowiedzialności za nie. Dla T. Kotarbińskiego odpowiedzialności rodziców za dziecko to imperatyw, a nie jedynie wyraz ich dobrej woli ${ }^{22}$. Silny wpływ na kształt wartości ma środowisko rodziny i grupy rówieśniczej. Niewątpliwie dzieci uczą się od rodziców, naśladują ich. Zderzenie się treści oddziaływań rodziny, grupy społecznej, instytucji rzeźbi wymiar wartości jednostki ${ }^{23}$. To za pomoca języka interpretujemy i proponujemy dzieciom świat. Ta odpowiedzialność za kształt dialogu, jaki prowadzi się z dzieckiem, przybiera postać odpowiedzialności o charakterze substytucyjnym $^{24}$.

\footnotetext{
18 [1999: 3-51]

19 [Olbrycht 1999: 11-12, 14]

${ }^{20}$ [Jonas 1996: 174-180].

21 [Gołąb 1980: 163-166].

22 [1986: 97-98]

23 [Rybczyńska, Olszak-Krzyżanowska 1999: 72].

24 [Levinas 2002: 101].
} 
Inny charakter niż odpowiedzialność naturalna, posiada odpowiedzialność ustanowiona przez nadanie lub przyjęcia zadania, czyli odpowiedzialność kontraktowa, zwana „sztuczną”. W przypadku tej odpowiedzialności, jej moc wiążąca bierze się z przyjęcia umowy. Inną cechą odróżniająca ją od odpowiedzialności naturalnej, jest fakt, iż można z niej zrezygnować lub zostać zwolnionym na skutek zaniedbania obowiązków a nie $\mathrm{z}$ czystej nieodpowiedzialności ${ }^{25}$. Przykładem odpowiedzialności kontraktowej jest odpowiedzialność nauczyciela, lekarza, urzędnika, sędziego. Warto też pamiętać o powszechnie występujących $\mathrm{w}$ funkcjonowaniu społecznym umowach o charakterze cywilnoprawnym, wskazanych w aktach prawnych, jak np. w polskim kodeksie cywilnym, umowy nazwane (sprzedaż, pożyczka, najem i inne) oraz swobodnie konstruowanych przez jednostki na zasadzie swobody umów. Jeszcze innym rodzajem odpowiedzialności, wyrosłym na bazie nad-obowiązkowości jest odpowiedzialność supererogacyjna, wychodząca poza obowiązek. Należy podkreślić, że spełnianie aktów supererogacyjnych jest czymś dobrym, jednakże nie czynienie ich, nie jest czymś moralnie złym.

R. Ingarden wyróżnił kilka typowych sytuacji zachodzenia fenomenu odpowiedzialności. Pierwszą sytuacją jest ta, w której jednostka ponosi / jest odpowiedzialna niezależnie od tego, czy poczuwa się do odpowiedzialności, czy jest faktycznym sprawcą czynu. Druga sytuacja dotyczy zjawiska poczuwania się do odpowiedzialności. Jednostka może poczuwać się do odpowiedzialności, chociaż nie jest faktycznym sprawcą czynu. Kolejną sytuacją mówienia o fenomenie odpowiedzialności jest zjawisko pociągania do odpowiedzialności, które może mieć miejsce nawet wtedy, kiedy jednostka nie będzie faktycznym sprawcą czynu, jak i wtedy, kiedy jednostka nie poczuwa się do odpowiedzialności. Cechą istotną sytuacji pociagania do odpowiedzialności jest bierny charaktery jej znoszenia przez możliwy pomiot odpowiedzialności. Ostatnią sytuacją fenomenu odpowiedzialności jest działanie odpowiedzialne $^{26}$. Podkreślenia wymaga fakt, że trzy pierwsze sytuacje dotyczą czynów już dokonanych, a więc mają na względzie zaistniałe skutki działań. Jedynie „działanie odpowiedzialne" może dotyczyć przyszłości. Ingarden wskazał na takie ujęcie odpowiedzialności w ramach, którego występuje odpowiedzialność „po czynie”, i odpowiedzialność „,przed czynem”. Odpowiedzialność „,po czynie” spada na kogoś za to, co uczynił, i jest konsekwencją dokonania czynności. Odpowiedzialność „,przed czynem” jest gotowością do poniesienia konsekwencji, jakie pociagnie za sobą postępowanie ${ }^{27}$.

W ostatnim czasie wiele uwagi poświęca się mówieniu o odpowiedzialności biosferycznej, w której przedmiotem odpowiedzialności jest świat przyrody. Zaobserwować można żywe zainteresowanie problematyką ekologiczną. Chwalebne jest, jeśli motywem dla odpowiedzialnych działań wobec świata przyrody, jest postawa wrażliwości i świadomości biosferycznej. Jeśli jest nim interes gatunkowy, też dobrze. Świadomość zagrożeń daję również impuls do konstruowania norm o charakterze prawnym, mających na celu ochronę świata przyrody, zaś przepisy prawne oddziaływają w dalszym stopniu na zachowania jednostek $\mathrm{i}$ zbiorowości $\mathrm{w}$ przedmiocie dbania $\mathrm{o}$ środowisko naturalne. Możemy w tym względzie wyróżnić dwa kierunki oddziaływań prawnych: perspektywiczny i retrospektywny. Normy moga kształtować działanie człowieka w przyszłości, poprzez wprowadzanie określonych reguł, zasad uwzględniających potrzeby środowiska naturalnego (np. limity emisji $\mathrm{CO}_{2}$, emitowania

\footnotetext{
${ }^{25}$ [Jonas 1996: 175-176, 180].

${ }^{26}$ [1972: 73-97]

27 [1989: 295]
} 
substancji szkodliwych). Ponadto występują normy sankcjonujące nieprzestrzeganie standardów prawnych, dotyczących ochrony środowiska naturalnego. Zauważyć trzeba, że samo istnienie abstrakcyjnej sankcji prawnej powoduje, że człowiek (adresat normy prawnej) nie podejmuje się pewnych działań, szkodliwych wobec świata przyrody. Oddziaływanie prawne ma zatem, w przeważającej mierze znaczenie perspektywiczne. Jedynie naruszenie normy prawnej i uruchomienie sankcji powoduje odpowiedzialność o znaczeniu retrospektywnym. Tym samym odpowiedzialność biosferyczna nie zostaje zamknięta $\mathrm{w}$ sferze moralnych powinności jednostki, ale wkracza $\mathrm{w}$ świat normalizacji prawnych. Co za tym idzie, są takie działania wobec świata natury, za które człowiek ponosi odpowiedzialność prawną, związaną z wymierzeniem kary. Nie wszystkie przejawy działalności człowieka podlegają jednak normalizacji. Obok charakteru prawnego ważna rolę odgrywa moralny wymiar odpowiedzialności biosferycznej. Pomocna przy dokonywaniu wyborów jest zasada minimalizacji cierpienia. Odpowiedzialność za przyrodę odsyła do całokształtu ludzkiej egzystencji. Zauważa, że konsekwencje szkodliwych ludzkich działań wobec świata natury odczują ludzie, jeśli nie za swojego bytowania, to na pewno spadną one na przyszłe pokolenia. Ta forma odpowiedzialności za to, co dopiero będzie, jest postacią odpowiedzialności perspektywicznej.

Zarzut ekologicznej krótkowzroczności przybiera na sile, zdaniem D. Birnbachera w obliczu zaostrzających się problemów ekologicznych. Sama przyszła egzystencja gatunkowa ludzkości staje się jednym z problematycznych wątków. Nierzadkie są głosy, że im większą wiedzą o odległych potencjalnych szkodach ludzkość dysponuje, tym liczniejsze mogą być spsoby zapobiegania szkodom, jak też, tym większy ciężar odpowiedzialności za przyszłość spoczywa na ludzkich czynach i zaniechaniach. Obwiązki wobec przyszłych pokoleń zwiazane są w pozytywną oceną przyszłego bytu a sama odpowiedzialność za przyszłość rodzi się z troski o przyszłe dobro. ${ }^{28}$.

Zauważyć należy, że z punktu widzenia ontologicznego, człowiek jest jednak odpowiedzialny, bez względu na rzeczywiście podejmowane działania. Bycie odpowiedzialnym określa ludzką egzystencję a tak pojętej odpowiedzialności nie można się zrzec. Niezależnie od tego, czy jednostka czuje się odpowiedzialną, czy zostanie pociągnięta do odpowiedzialności, czy działa odpowiedzialnie... pozostaje odpowiedzialna, nawet wtedy, gdy działa nieodpowiedzialnie. Tak rozumianej odpowiedzialności przeciwstawia się zjawisko niezachodzenia odpowiedzialności. Moralność dzieje się w języku za sprawą wypowiadanych ocen i norm, stąd ludzkie działania podlegają ocenianiu przez zbiorowość, w której jednostka funkcjonuje. To ocenianie może być dokonywane przez grupę/ społeczność, jak też może przybrać formę zinstytucjonalizowana, gdzie zachowanie jednostki podlega ocenie sądu, dlatego w przypadku odpowiedzialności rozumianej w sensie nabywanej kwalifikacji ocennej, mamy i czyny odpowiedzialne $i$ przeciwstawne im czyny nieodpowiedzialne.

Do odpowiedzialności ontologicznej podobna pod pewnymi względami jest samoodpowiedzialność. Cechą istotną samoodpowiedzialności jest fakt, że to jednostka sama pociąga siebie do odpowiedzialności i poczuwa się do bycia odpowiedzialną. Kompasem przy dokonywaniu wyborów między tym, co odpowiedzialne a nieodpowiedzialne jest jej sumienie moralne. Chociaż może ona dopuścić się czynów nieodpowiedzialnych, podejmuje się odpowiedzialności za spowodowany stan rzeczy. To „bycie odpowiedzialną” niezależnie od charakteru czynów, zbliża samoodpowiedzialność do odpowiedzialności ontologicznej. Jednakże samoodpowiedzialności bazuje na sumieniu

${ }^{28}$ [1999: 6-7, 21-22] 
jednostki, natomiast ta druga, porusza się w sferze całokształtu ludzkiej egzystencji. Sumienie wzywa ,wbrew oczekiwaniom a nawet wbrew woli"29.

$\mathrm{Z}$ przytoczonych tu postaci odpowiedzialności widać, że perspektywy mówienia o odpowiedzialności funkcjonują $\mathrm{w}$ ramach pewnego modelu. Stanowi go sądowy model odpowiedzialność, z uwagi na poniższe charakterystyczne elementy. Kiedy pada pytanie o odpowiedzialność ważne jest, po pierwsze, kto jest podmiotem odpowiedzialności. Za podmiot uchodzi człowiek, który jest za „coś” odpowiedzialny. Właśnie owo „za co” kreśli kolejny element - przedmiot odpowiedzialności. Przedmiotem odpowiedzialności może być dziecko, przyroda, uczeń, pacjent, czyny ludzkie... Odpowiedzialność zostaje nałożona na jednostkę przez instancję, którą może być społeczeństwo, sąd, człowiek. Obok tego, że odpowiedzialność zostaje nałożona, zostaje ona także wyegzekwowana. Obecny jest, więc trybunał przed jakim jednostka odpowiada. Rolę trybunału/egzekutora odpowiedzialności może pełnić przykładowo: Bóg, sąd, sumienie. Ingardenowska sytuacja ponoszenia (bycia) odpowiedzialności odnosi się do pytania - kto jest odpowiedzialny? Poczuwanie się do odpowiedzialności, dotyka pytania o przedmiot odpowiedzialności - za co, jest odpowiedzialny? W przypadku pociagania do odpowiedzialności mamy, w ramach modelu, instancję nakładającą odpowiedzialność. Trybunał odsyła do zapytania o to przed kim jednostka odpowiada, i na ogół jego rolę pełni instancja, która pociągnęła jednostkę do odpowiedzialności.

\section{Zakończenie}

„Odpowiedzialność - zwyczajne słowo, od wieków używane przez prawników, a nadużywane przez wychowawców i różnego typu mentorów - staje się w naszych czasach pierwszym słowem etyki, a etyka „rozumiana jako odpowiedzialność” - pierwszym słowem filozofii”" ${ }^{30}$. Dyskusje o odpowiedzialności odbywają się w sferze prawa, moralności... To decyduje o charakterze samej odpowiedzialności oraz rodzaju kar, jakie zostają nałożone za czyny nieodpowiedzialne. Chwalenie za odpowiedzialne działanie, samo w sobie stanowić może już nagrodę dla jednostki. W przypadku nieodpowiedzialnych czynów, wyraz społecznej dezaprobaty może stanowić dla jednostki dolegliwość porównywalną z wymiarem sankcji prawnej.

Kolejna istotna kwestia dotyczy tego, czy problematyka odpowiedzialności poruszana jest w ramach ontologicznych, czy wypowiadanych kwalifikacji ocennych. To warunkuje wymiar odpowiedzialności. Ontologiczna odpowiedzialność towarzyszyć będzie zawsze człowiekowi, niezależnie od zachodzenia takich aktów psychicznych jak: świadomość odpowiedzialności, poczucie odpowiedzialności, czy pociaganie do odpowiedzialności. Zupełnie inaczej niż przy odpowiedzialności nabywanej $\mathrm{z}$ uwagi na wypowiadane kwalifikacje ocenne, które to stają się podstawą do orzekania o byciu lub nie byciu odpowiedzialnym. Nieodpowiedzialność rozumiana jest jako wyraz oceny negatywnej. Niezachodzenie odpowiedzialności, stan nie-odpowiedzialności możliwy w przypadku odpowiedzialności ontologicznej wiąże się z oderwaniem odpowiedzialności od ludzkiej egzystencji, gdyż tylko tak, możliwa jest nie-odpowiedzialność. Warto jednak zauważyć jeszcze inny możliwy fenomen mówienia o nieodpowiedzialności, obok przejawu wyrażanej dezaprobaty. Odpowiedzialność, związana z kwalifikacją ocenną jednostki, rozróżnia czyny odpowiedzialne (dobre, słuszne moralnie) i czyny nieodpowiedzialne (złe, szkodliwe moralnie). Pozostawia to przestrzeń dla takiego rodzaju działań, które ani nie sa

\footnotetext{
${ }^{29}$ [Heidegger, 1994: 387]

30 [Filek 1996: 13]
} 
odpowiedzialne, ani nieodpowiedzialne. Cechować je może indyferentyzm z uwagi na zjawisko zachodzenia odpowiedzialności. Wypowiedzenie zdania o treści - „on nie jest odpowiedzialny", nie oznacza ani, że jest odpowiedzialny (ocena), ani że jest nieodpowiedzialny (ocena), wskazuje, iż możliwym sprawcą czynu może być ktoś inny, i w pełni zdejmuje z człowieka odpowiedzialność za dany czyn. Jednakże na gruncie odpowiedzialności ontologicznej, takie powiedzenie o kimś, że nie ponosi odpowiedzialności, nie pozbawia człowieka odpowiedzialności w ogóle, gdyż ta mu zawsze towarzyszy, co najwyżej może oznaczać, że dany człowiek nie jest faktycznym sprawcą czynu, o który się go posądza. Zdejmowanie odpowiedzialności za dany czyn w ramach odpowiedzialności funkcjonującej w sensie nabywanych kwalifikacji ocennych, wiąże się z opuszczeniem perspektywy odpowiedzialności.

Globalne skutki problemu $\mathrm{CO}_{2}$, szkody klimatyczne, nieodwracalne niszczenie środowiska, ginięcie gatunków stają się impulsem do dyskusji nad problemem odpowiedzialności za biosferę, odpowiedzialności za przyszłe pokolenia. „Odczuć” przyrodę, ,zidentyfikować” się z nią to coraz głośniejsze postulaty.

Sprawą godną uwagi pozostaje fakt, że w zależności od tego, kogo odpowiedzialność dotyczy, słyszy się o odpowiedzialności lekarza, nauczyciela, sędziego, rodzica, polityka. To pociąganie, czy przypisanie im odpowiedzialności odbywa się $w$ ramach funkcjonującego sądowego modelu odpowiedzialności. Żeby mówić o odpowiedzialności potrzebujemy sprawcy czynu, przedmiotu, instancji i trybunału przed jakim odpowiedzialność zostanie wyegzekwowana. To wyegzekwowanie niejednokrotnie przyjmuje postać wymierzenia kary. Tak odpowiedzialność posyła nas w ręce sprawiedliwości. 


\section{Bibliografia}

Platon, 1960: Prawa 837 E - 874 A, Warszawa.

Wesoły, M. 1994: Demokryt o pogodzie ducha, wychowaniu i polityce, w: Symbole philologorum posnaniensium graecae et latinae, Wolumen X, Poznań.

Filek, J. 1996: Ontologizacja odpowiedzialności. Kraków.

Filek, J. 2003: Filozofia odpowiedzialności XX wieku. Kraków:Wydawnictwo Znak.

Fichte, J.G. 1996: Teoria Wiedzy, T. I, Warszawa.

Kołakowski, 1. 1997: Mini wykłady o maxi sprawach. Kraków.

Kotarbiński, T. 1934: Czyn, Lwów: Biblioteczka Filozoficzna.

Olbrycht, K. (red.), 1999: Edukacja aksjologiczna, T. IV, Katowice.

Jonas, H. 1996: Zasada odpowiedzialności. Kraków.

Gołąb,A. Problemy psychologii moralności, w: Jankowski, H. (red.), 1980: Etyka, Warszawa: PWN

Kotarbiński, T. 1986: Medytacje o życiu godziwym.. Warszawa.

Rybczyńska, D.A., Olszak-Krzyżanowska, B. 1999: Aksjologia pracy socjalnej-wybrane zagadnieni. Katowice: Wyd. „Śląsk".

Levinas, E., 2002: Całość i nieskończoność. Esej o zewnętrzności. Warszawa: Wyd. Naukowe PWN.

Birnbacher, D., 1999: Odpowiedzialność za przyszłe pokolenia. Warszawa, Terminus 19.

Ingarden, R., 1972: Książeczka o człowieku. Kraków: Wyd. Literacki.

Ingarden, R. 1989: Wyktady z etyki, Warszawa.

Ossowska, M., 1983: O czlowieku, moralności i nauce. Warszawa.

Ossowska, M. 1994: Podstawy nauki o moralności, Wrocław - Warszawa - Kraków: Ossolineum.

Znamierowski, Cz. 1957: Wina i odpowiedzialność. Warszawa: PWN

Dokurno, J. 1993: Odpowiedzialność, w: Bartmiński, J., Mazurkiewicz-Brzozowska, M. (red.), 1993: Nazwy wartości. Studia leksykalno-semantyczne, Lublin: UMCS

Skorupka, 1988: Stownik wyrazów bliskoznacznych, Warszawa

Groicki B. 1559: Porzadek sąów, w: Stownik polszczyzny XVI wieku, (red.), Mayenowej, M.R., 1966-1991: t. I-XX (AOD), Wrocław - Warszawa - Kraków.

Mickiewicz, A. 1979: Pan Tadeusz. Warszawa: Czytelnik.

Mickiewicz, A., (1843 - 1846): Pisma Towianistyczne, Wydanie Narodowe za: Mayenowa, M. R. (red.), 1962: Stownik jezzya Adama Mickiewicza. Wrocław.

Daniłowski, W. 1908: Notatki do pamiętników. za: Doroszewski, W. (red.), 1958: Słownik języka polskiego. Warszawa.

Heidegger, M. 1994: Bycie i czas. Warszawa 